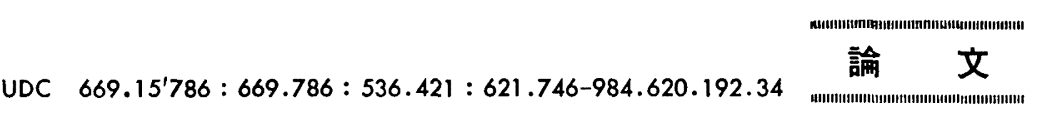

$\mathrm{Fe}-\mathrm{N}$ 系の減圧下における気孔生成*

大野悟**.宇田雅 広***

\title{
Blowhole Formation in Fe-N System under Reduced Pressures
}

\author{
Satoru OHNo and Masahiro UDA
}

\begin{abstract}
Synopsis :
The blowhole formation in the $\mathrm{Fe}-\mathrm{N}$ system during solidification under the reduced pressures has been studied by using a levitation melting apparatus. Molten irons containing various nitrogen contents were cast into the copper mold under various reduced pressures. Blowholes were evaluated by the radiographic inspection and the examination of sectioned portions of the ingot.

The results are summarized as follows:

1) The contents of nitrogen for blowhole formation are decreased by reducing external pressure at solidification and are approximately $25 \%$ lower than the equilibrium solubility of nitrogen at the melting point of iron and furthermore are propotional to square root of their external pressures in the range of 1 atm. to 10 torr. However, below 10 torr. external pressures, the critical nitrogen contents for blowhole formation are independent of their external pressures and take almost a constant value of $40 \mathrm{ppm}$.

2) The growing process of blowholes is discussed from the point of view of the amount of gas available from the enriched layer of solute at the solid-liquid interface during solidification.
\end{abstract}

\section{1. 緒言}

金属凝固時の気孔生成は，凝固金属の健全性と直接関 わる問題であることから, 種々の金属を対象に多くの研 究が行われている.

これら研究の中でも，とくに鉄凝固時の気孔生成につ いては，炭素-酸素間の反応 (CO ガス) による気孔生 成現象が系統的に研究されており, 気孔生成機棈の一部 が明らかにされつつある1〜6)。

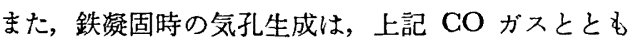
に, 水素, 窒素等のガス成分の存在によつても著しい影 響を受けることも指摘されているが78)，それらガス成 分, とくに窒素に関する系統的研究は少なく9) 12), そ の影響の詳細は必ずしも明らかではない.

著者らはこれまで, レビテーション溶解した金属を銅 モールド中に鋳込む方法を用い, 種々の金属を対象に, 比較的速い凝固速度（約 $1 \mathrm{~cm} / \mathrm{s}$ ) に打ける水素あるいは 窒素による気孔生成現象を調査するとともに，その気孔 生成現象の特徵ならびにアーク溶接金属の気孔生成現象 などとの関連を明らかにしてきた13)〜17)。

本研究は, 上述の研究の一環として, 減圧下で凝固す
る金属の気孔生成現象と気孔生成におよほすす諸因子の影 響を明らかにすることを目的に，急冷凝固させた純鉄の 気孔生成現象と窒素含量ならびに凝固時雲因気圧力の関 係を調査し，その気孔生成機構について検討を行つたも のである.

\section{2. 実 験 方 法}

本実験に使用した純鉄は，電解鉄（昭和電工製了トミ ロン）を真空溶解し, 熱間圧延により $10 \mathrm{~mm} \phi$ の丸棒 に圧延したもので，この純鉄丸棒を約 $3 \mathrm{~g}(9 \mathrm{~mm} \phi \times 6$ $\mathrm{mm})$ の大きさに機械加工し, 溶解用試料とした.

Table 1 に溶製した純鉄試料の主な化学成分を示す.な お，装置の関係上，試料は上部より孯垂保持する必要が あるため, 各溶解用試料には㣰垂用の純鉄細線 $(0.1 \mathrm{~mm}$ 申)をループ状にパーカッション溶接し,実験に供した.

Table 1. Chemical composition of pure iron used in experiments.

\begin{tabular}{c|c|c|c|c|c|c|c}
\hline \multicolumn{7}{c}{ ELEMENT . \% } \\
\hline$c$ & Si & Mn & P & S & $C u$ & 0 & $N$ \\
\hline 0.005 & 0.005 & 0.006 & 0.004 & 0.004 & 0.004 & 0.033 & 0.002 \\
\hline
\end{tabular}

* 昭和 52 年 10 月本会講演大会にて発表 昭和 53 年 11 月 2 日受付 (Received Nov. 2, 1978)

** 金属材料技術研究所 (National Research Institute for Metals, 2-3-12 Nakameguro Meguro-ku 153)

*** 金属材料技術研究所理博 (National Research Institute for Metals) 


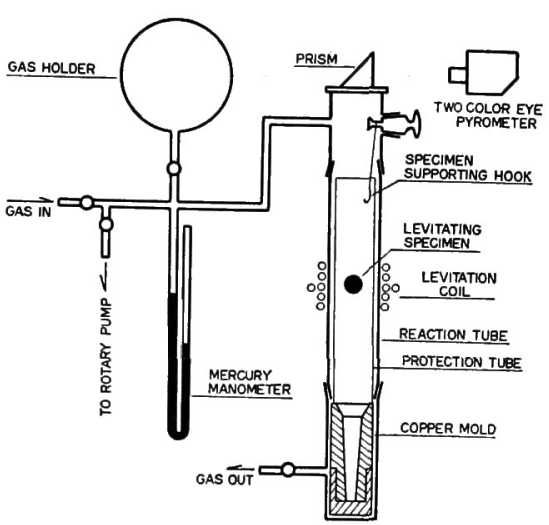

Fig. 1. Schematic diagram of levitation melting apparatus.

Fig. 1 に，本実験に使用したレビテーション溶解反 応装置の概略図を示す．本装置は，1 気圧以下の任意の 雾囲気圧力下に招いて試料を浮揚溶解することができる とともに，その凝固時雾囲気圧力を独立に調節できるよ らに構成されている.

本装置による試料の溶解は，まず試料保持用フックに より純鉄試料を眯垂し, 反応管内の所定の位置（レビテ ーションコイル内）にセットしたのち, 油回転ポンプに より系内を約 10-3 Torr 程度に排気する. 次に, 系内 に純窒素を導入してガス溜めならびに反応管内の圧力を それぞれ所定の窒素雾用気圧力としたのち, 試料を浮揚 溶解し, 反応管内の窒素雲聿気と十分な平衡を達しせし めるに必要な時間 ( $2 \mathrm{~min}$ ) 所定の温度に保持する.

溶融試料の凝固は, 所定の反応時間経過後, ガス溜め のコックを開け，反応管内の圧力を所定の圧力に調節す ると同時に試料を下部の銅モールド (内径約 $6 \mathrm{~mm}$ ) に 落下させて急冷凝固させる.なお, ガス溜めのコック操
作時より試料落下までの時間は $10 \mathrm{~s}$ 以内である. た, 試料の凝固速度は前報 17$)$ の結果より約 $1 \mathrm{~cm} / \mathrm{s}$ と推 定される.

試料の溶解条件は, 溶解温度 $2000 \pm 20^{\circ} \mathrm{C}$, 溶解時間 $2 \mathrm{~min}\left(2000^{\circ} \mathrm{C}\right.$ 致達後) であり, 測温には 2 色高温計 (シグマ電子工業製) を使用した. なお，この溶解条件 に打ける平衡窒素溶解量は， $P_{\mathrm{N}_{2}}=1 \mathrm{~atm}$ に拈いて 525 土5 ppm であつた.

凝固試料の気孔検査は, X線検査ならびに断面検査に より行つた. また, 凝固試料の窒素分析には, LECO社 製酸素·窒素同時分析装置を使用した。

\section{3. 実 験 結 果}

Photo. 1 に, 凝固試料のX線透過写真の一例を示す. この写真に見られるように, 試料の窒素含量がほぽ同一 であつても, 凝固時䨌囲気圧力の増大とともに気孔発生 量は減少し, ある圧力以上になると気孔の発生は全く認 められなくなり, 気孔生成現象は溶鉄中の窒素含量と之 もに凝固時雲囲気圧力によつても大きな影響を受けてい ることがわかる.

Fig. 2 には, 気孔生成の有無と凝固試料の窒素含量 ならびに凝固時雾囲気圧力との関係を示す. 図中, 黒丸 は凝固試料中に気孔の発生が認められたもの，白丸は気 孔の発生が認められなかつたものであり，実線はその境 界領域, 寸なわち気孔生成の臨界窒素含量之凝固時雾囲 気圧力の関係を示したものであるまたた，一点鎖線およ び二点鎖線は，融点に括ける純鉄の液相および固相の平 衡窒素溶解量 ${ }^{18)}$ 19) と霛团気圧力の関係を示したものであ る.

Fig. 2 より, 気孔生成の臨界窒素含量は, 凝固時雾 四気圧力が約 10 Torr を境にして特徽的な 2 つの領域

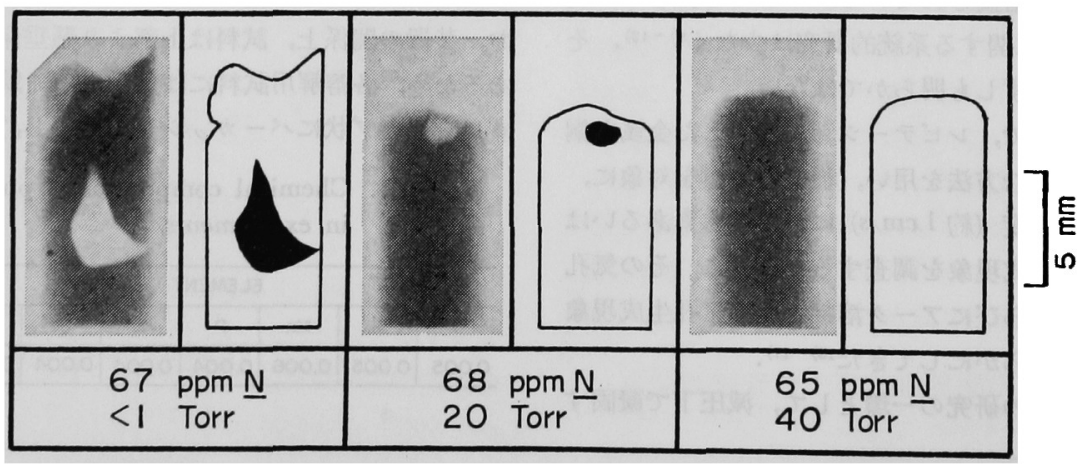

Photo. 1. Radiograph of blowholes in $\mathrm{Fe}-\mathrm{N}$ specimens solidified under various reduced pressures and at a constant nitrogen content (65-68ppm N). Right side of radiograph shows its sketch. 


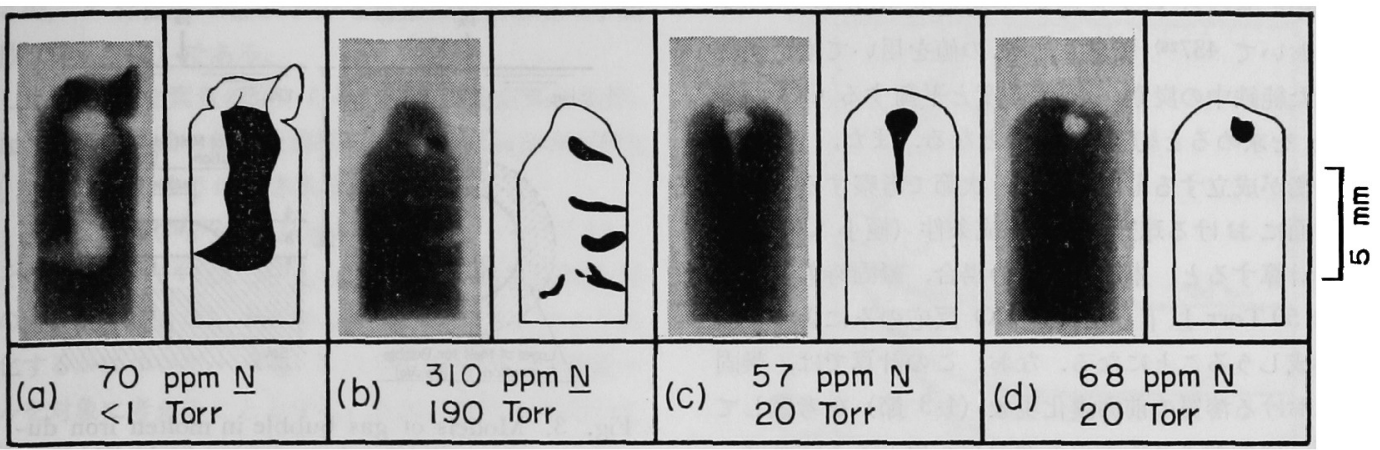

Photo. 2. Radiograph of blowholes in $\mathrm{Fe}-\mathrm{N}$ specimens solidified under various reduced pressures and nitrogen contents. Right side of radiograph shows its sketch.

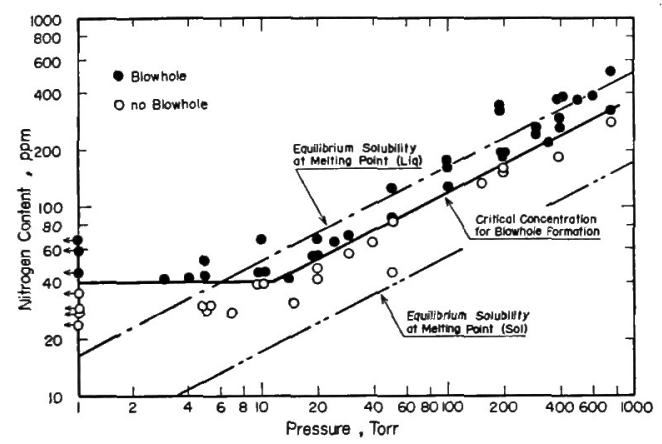

Fig. 2. Relationship between critical nitrogen conients for blowhole formation and external pressures during solidification.

に分かれていることがわかる、すなわち，凝固時雾囲気 圧力が約 10 Torr 以上では, 気孔生成の臨界窒素含量 は凝固時雾囲気圧力の $1 / 2$ 乗に比例して増加し, しかも その值は同じ圧力下に批る液相および固相の平衡窒素 溶解量（融点）の中間の值を示している.

一方, 凝固時䨌囲気圧力が約 10 Torr 以下では, 気 孔生成の臨界窒素含量は凝固時雾囲気圧力に関係なくほ ぼ一定の值 (約 $40 \mathrm{ppmN}$ ) を示している.このこと は, この領域の気孔生成現象がその外圧とともに溶鉄の 静生などの因子の影響をも受けていることを意味し，減 圧下に拈ける気孔生成現象の特徽的領域と考古られる.

Photo. 2 には, 凝固試料中に観察された 4 種類の気 孔発生形態, 円筒状気孔 (Photo. 2-a), くさび状気孔 (Photo. 2-b), 引忛柴状気孔 (Photo. 2-c) および球状 気孔 (Photo. 2-d) のそれぞれ典型的な一例を示す.

ここで, 円筒状気孔は, 器壁近傍（初期㠜固部）で発 生した気孔が試料中央部（最終凝固部）一向かつて急激 に成長し, 試料中央部で円筒状の大きな気孔を形成する 場合である. また，Photo. 2 中にその窒素分析值を示
したが、このような円筒状気孔の発生した試料の窒素含 量は, いずれる Fig. 2 における気孔生成の臨界窒素含 量よりも著しく高い値を示した。

次に, くさび状気孔は, 器壁近傍で発生した気孔が凝 固組織に沿つて細長く成長することを特徵とするもので ある.この形態の気孔が形成された場合の窒素含量もま た気孔生成の臨界窒素含量よりも高い值を示した。

引け巣状気孔は, 試料中央部で発生した気孔がほぼ垂 直に成長し, 引け巣様の気孔を形成する場合である。こ の引け策状気孔は, その窒素含量が気孔生成の臨界窒素 含量とほぼ同程度の場合にのみ発生が認められた。

球状気孔は, 字義通り球形の気孔であるが，その発生 位置および大きさは引け巣状気孔の頭部之類似してい る. また,この気孔の認められた試料の窒素含量は, 引 け巣状気孔の場合と同様に, 気孔生成の臨界窒素含量と 同程度の值であり, 球状気孔は引け巣状気孔の頭部のみ が残留したものと考えられる.なお, この球状気孔の大 きさは約 $0.5 \mathrm{~mm}$ 以上のものが主体であり, 他の気孔 発生形態を示寸条件下においても顕微鏡的サイズ $(0.1$ $\mathrm{mm}$ 以下）の球状気孔は全く認められなかつた。 また， 球状気孔の場合を除き, 気孔発生点の試料上面（溶鉄表 面）からの深さは，5～10 mm の範囲に最も多く認めら れた。

\section{4. 考察}

\section{$4 \cdot 1 \mathrm{CO}$ 反応による気孔生成の可能性について}

Table 1 に示したように，本実験に使用した純鉄試料 には, ガス生成成分として窒素の他に炭素および酸素が それぞれ0.005\% および $0.033 \%$ 含有されており，減圧 下に拈いてはその反応により生成した $\mathrm{CO}$ ガスが気孔 生成に影響を和上ぼすことる考えられる，そこで，この $\mathrm{CO}$ 反応による気孔生成の可能性について考えてみる。 
溶鉄中に打ける $\mathrm{CO}$ 反応の平衡定数 $K_{\mathrm{CO}}$ は， 1550 ${ }^{\circ} \mathrm{C}$ において 43720) であり，この值を用いて本実験に 使用した純鉄中の炭素, 酸素濃度と平衡する CO の分 代 $P_{\text {Co }}$ を求めると約 55 Torr となる. また，このよ らな平衡が成立するものとして，次節で考察するよらな 凝固界面にお汀る球冠気泡の形成条件（極小 $\mathrm{CO}$ 濃度 積）を計算すると，本純鉄試料の場合，凝固時雾囲気压 力が約 50 Torr 以下となれば CO 反応のみによつて気 孔を形成しうることになる。なお，この計算では，凝固 過程に打汀る溶質の前面濃化現象 (4.3 節) を考虙して おらず，炭素拉よび酸素の前面濃化が生じるとすれば， $\mathrm{CO}$ 反応による気孔生成の可能性を有する凝固時雾团気 殴力はさらに上昇することとなる。

このよらに, 本実験に使用した純鉄試料の炭素, 酸素 濃度は, 減圧下（約 50 Torr 以下）に扰いて CO 反応 による気孔を生成しらる可能性を有していることにな る.

しかしながら，Fig. 2 に見られるように，凝固試料 の気孔発生挙動にはCO反応による影響が全く認められ ず，凝固試料の窒素含量のみに強く依存している，たと えば，凝固時雾囲気圧力が約 10 Torr 以下に批汀る気 孔生成の臨界窒素含量 (約 $40 \mathrm{ppm}$ ) と平衡する窒素分 压についてみると約 $6 \operatorname{Torr}\left(1550^{\circ} \mathrm{C}\right){ }^{18)}$ である. した がつて, CO 反応がこの圧力下での気孔生成に関与する とすれば，気孔生成の主因は CO ガスであることにな るにもかかわらず，実際の気孔生成現象は窒素濃度に依 存して拉り，本実験では CO 反応による気孔生成の可 能性が極めて小さいことを示している.

このように，本実験に怙いてはCO 反応に上る気孔 生成の積極的証左は得られていない。そこで, 次節から の考察では, 気孔は窒素によつて生したものと仮定し検 討を進めることとする.

\section{2 溶鉄中における気泡形成条件}

金属凝固時に和汀る気孔生成の成否は, 与兄られた物 理化学的条件下に批いて溶融金属中に気泡を形成しらる か否かによつて決定される.したがつて，Fig. 2 に見 られるように, 気孔生成の臨界窒素含量が凝固時䨌囲気 圧力によつて著しい影響を受ける原因は，溶鉄中に打け る窒素ガス気泡の形成条件が需囲気圧力によつて変化し たためと考えられる。

そこでまず，溶鉄中に拁ける気泡の安定存在条件の面 より，Fig. 3 に示すような球気泡扣よび球冠気泡が窒 素により形成される場合の形成条件について考えること とする．なおここで，球気泡は溶鉄が㠜固点まで冷却さ れる間に溶鉄中に気泡が形成される場合, 球冠気泡は溶

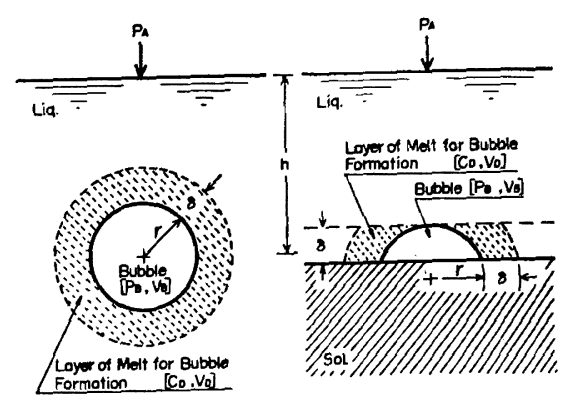

Fig. 3. Models of gas bubble in molten iron during solidification. (a) : spherical bubble, (b) : spherical cap bubble where, $P_{\mathrm{A}}$ : external pressure, $h:$ distance from surface of molten iron to center of bubble, $r$ : radius of sphere or radius of curvature of spherical cap of bubble, $P_{\mathrm{B}}$ : internal pressure of bubble, $V_{B}$ : volume of bubble, $\delta:$ thickness of diffusion layer, $C_{\mathrm{D}}$ : concentration of solute in diffusion layer and $V_{\mathbf{D}}$ : volume of diffusion layer.

鉄の凝固過程に扣いて凝固界面に気泡が形成される埸合 にそれぞれ対応するモデルである.

周知のように, Fig. 3 に示したような曲率半径 $r(\mathrm{~cm})$ の気泡が外圧 $P_{\mathrm{A}}(\mathrm{atm})$ の下で溶鉄表面から深さ $h(\mathrm{~cm})$ に存在する場合の安定存在条件, すなわちその気泡の内 压 $P_{\mathrm{B}}(\mathrm{atm})$ は次式を満足しなければならない。

$$
P_{\mathrm{B}} \geq P_{\mathrm{A}}+\rho h / 1013.25+1.974 \times 10^{-6} \sigma / r \cdots \cdots(1)
$$
ここで， $\rho$ および $\sigma$ はそれぞれ溶鉄の密度 $\left(\mathrm{g} / \mathrm{cm}^{3}\right)$ お よび表面張力 $(\mathrm{dyn} / \mathrm{cm})$ である.

ところで, この気泡内の窒素がすべてとの気泡周囲の 溶鉄から供給されたすのと仮定すると，（1）式を満足す るための気泡形成に必要な溶鉄の窒素濃度は, この気泡 内の窒素量を与え, かつその内圧と平衡する濃度以上で なければならないことになる。

いまここで, 内圧 $P_{\mathrm{B}}$, 体積 $V_{\mathrm{B}}\left(\mathrm{cm}^{3}\right)$ を有する気泡が 存在した場合を考えると, その気泡内の窒素量 $N_{\mathrm{B}}\left(\mathrm{cm}^{3}\right)$ (標準状態)は次式のように表される.

$$
N_{\mathrm{B}}=P_{\mathrm{B}} V_{\mathrm{B}} T_{\mathrm{o}} / T_{\mathrm{m}}
$$

ここで, $T_{\mathrm{o}}$ は標準状態の絶対温度 $(273.15 \mathrm{~K}), T_{\mathrm{m}}$ は 気泡内のガスの温度 $(\mathrm{K})$ である.

一方, 気泡周囲の溶鉄の窒素濃度は, 少なくともその 気泡内圧に相当する平衡窒素溶解量に等しくなければな らず，かつその気泡形成に関与する溶鉄が有限の体積 $V_{\mathrm{D}}\left(\mathrm{cm}^{3}\right)$ である (Fig. 3 参照) ことを考慮すると, $V_{\mathrm{D}}$ 内に含有される窒素量 $N_{\mathrm{D}}\left(\mathrm{cm}^{3}\right)$ （標準状態） は次式を 満足しなければならない。

$$
N_{\mathrm{D}} \geq K \sqrt{P_{\mathrm{B}}} V_{\mathrm{D}} \rho / 100
$$


ここで，K は温度 $T_{\mathrm{m}}$ に护ける溶鉄の窒素溶解の平衡 定数 (体積単位) である.

したがつて,窒素量の面からみた気泡の安定存在条件, すなわち気泡形成に必要な溶鉄の窒素濃度 $C_{\mathrm{M}}\left(\mathrm{cm}^{3} / 100 \mathrm{~g}\right.$ $\mathrm{Fe})$ は，次式のように表されることになる。

$$
C_{\mathrm{M}} \geq 100\left(N_{\mathrm{B}}+N_{\mathrm{D}}\right) / V_{\mathrm{D}} \rho
$$

そこで，この(4)式で与えられる気泡形成に必要な溶 鉄の窒素濃度 $C_{\mathrm{M}}$ が， $P_{\mathrm{A}}$ および $r$ につてどのように 変化するかについて，Fig. 3 に示した球扮よび球冠も デルを対象に考皃ることとする，なお，計算にあたつて は次のような仮定を設けた。

（i）溶鉄から気泡中への窒素の移動は拡散によつて 生しる.したがつて，気泡形成に関与する溶鉄層の厚さ

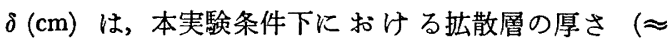
$10^{-4} \mathrm{~cm}$ ) に等しい（銅モールド中に鋳込まれた試料の 凝固完了までの時間は約 $0.3 \mathrm{~s}$ であり，この間に気泡の 形成・成長が生じることより，执散層を超えるような遠 距離からの窒素の移動は実質上無視できるものと考兄ら れる).

（ii）球冠気泡の高さは拡散層の厚さ $\delta$ 亿等しく，か つ抬散層前方の溶鉄は気泡形成に全く関与しない（後述 するように, 前面濃化現象によつてのみ気泡が形成され る場合にはほぼ妥当な仮定と考学られる)。

（iii）球冠気泡の接する固体（鉄）表面は完全な平面 であり，固相と気泡間に窒素の移動はない。

（iv）気泡内の窒素ガスの温度および気泡周囲の溶鉄 の温度は純鉄の融点 $(1809.15 \mathrm{~K})$ に等しい。

また，溶鉄の密度 $\rho$, 表面張力 $\sigma$ および窒素溶解の平 衡定数 $K$ には，それぞれ $7.02 \mathrm{~g} / \mathrm{cm}^{3}\left(1550^{\circ} \mathrm{C}\right){ }^{21)}$, $1700 \mathrm{dyn} / \mathrm{cm}\left(1539^{\circ} \mathrm{C}\right)^{22)}$ お。 よひ $35.6 \mathrm{~atm}^{-1 / 2} \cdot \mathrm{cm}^{3} / 100 \mathrm{~g}$ $\mathrm{Fe}\left(1536^{\circ} \mathrm{C}\right){ }^{18)}$ の值を使用した.

計算結果の一例として, 気泡の深さが溶鉄表面から 1 $\mathrm{cm}$ の場合の気泡曲率半径とその気泡を形成するに必要 な溶鉄の窒素濃度の関係を Fig. 4 に示す。同図にみら れるように，球気泡モデルに护ける気泡形成に必要な溶 鉄の窒素濃度は, 気泡曲率半径の增大ととるに減少する が，ある曲率半径において極小値を示したのち再び増加 している.これに対し, 球冠気泡モデルの気泡形成に必 要な溶鉄の窒素濃度は, 気泡曲率半径の增大とともに減 少し, ある曲率半径以上でほぼ一定の值（以下極小値） となつている。

ここで，この気泡形成に必要な窒素濃度の極小值につ いてみると，球気泡モデルの極小值は同圧力下の球冠気 泡モデルの極小值よりも著しく大きく，かつ低曲率半径 側にあることがわかる，また，溶鉄中に批りる窒索気泡

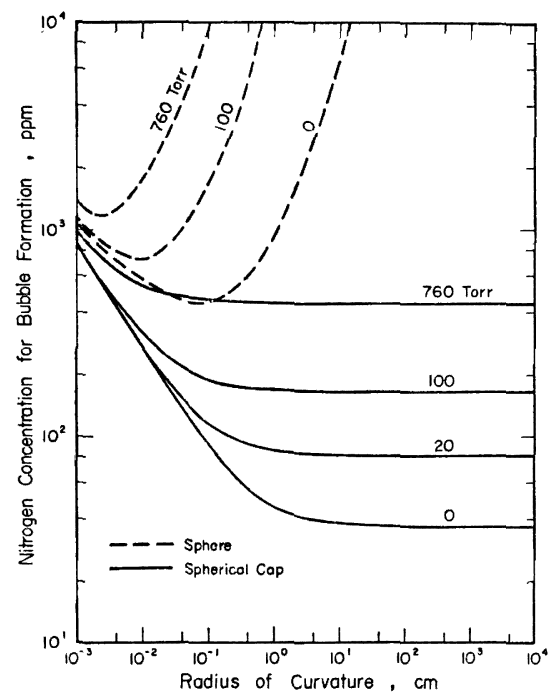

Fig. 4. Relationship between radius of curvature of bubble and nitrogen concentration in iron required for bubble formation under various external pressures.

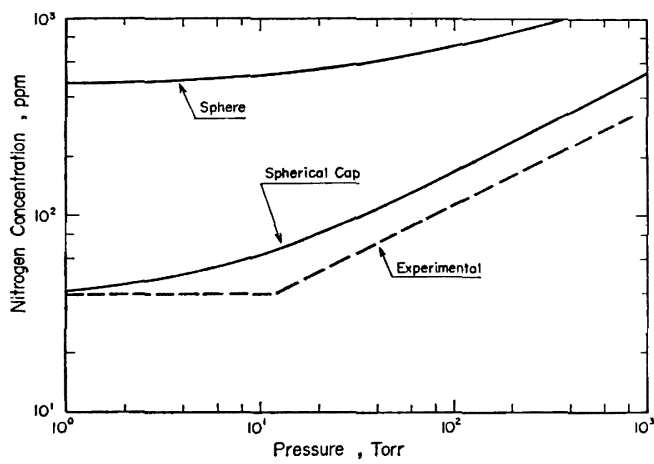

Fig. 5. Comparison of measured and calculated nitrogen concentration in iron required for blowhole formation under various external pressures during solidification.

の形成が，この極小值近傍の窒素濃度，曲率半径で生ず るものとすれば，球冠気泡は球気泡よりも容易に形成さ れうることになり，本実験に叔いて顕微鏡的サイズの球 状気孔が観察されなかつた原因の一端と考兄られる.

Fig. 5 に，気泡形成に必要な窒素濃度の極小值と外 压の関係を示す (図中実線)・な拈，図中の破線は本実験 で得られた気孔生成の臨界窒素含量と凝固時雾囲気圧力 の関係を示したものである.

同図より，球気泡モデルの極小空素濃度は，実験的に 得られた気孔生成の臨界窒素含量よりも著しく高く，そ の外压に対する挙動も著しく異なつて拈り，このモデル 
では実際の気孔生成現象を説明できないことがわかる。

一方, 球冠気泡モデルの極小窒素濃度は, 気孔生成の 臨界窒素含量よりも約 1.6 倍程高い值（約 10 Torr 以 上）であるが，その外圧に対する挙動は良好な対応を示 しており，このモデルが実際の気孔生成現象に近似した ものであることを示唆している.

また，この球冠気泡モデルに従えば，凝固時雾囲気圧 力に対する気孔生成の臨界窒素含量の挙動は次のように 考えることができる.

すなわち，凝固時雾囲気圧力約 10 Torr 以上におい て, 気孔生成の臨界窒素含量が雾囲気圧力の $1 / 2$ 乗に比 例する原因は，（1) 式で与えられる気泡内圧 $P_{\mathrm{B}}$ に対す る(1) 式右辺の第 2 項および第 3 項の寄与が小さい（た とえば, $h=1.0 \mathrm{~cm}, r=1.0 \mathrm{~cm}$ で第 2 および第 3 項の和 は約 7.8 Torr) ため, 気泡内圧は主として外圧によつ て決定される. したがつて，(3)式からわかるように， その気泡内圧と平衡する溶鉄の窒素濃度はほぼ外圧の $1 / 2$ 乗に比例することになる.

これに対し，凝固時雾囲気圧力が約 10 Torr 以下で は, 気泡内圧に対する $(1)$ 式第 2 項および第 3 項の寄与 が無視できず，たと光 $P_{\mathrm{A}}=0$ においてもそれらの和に 対応する窒素濃度が保存されねばならないことになる。 その結果として, 気孔生成の臨界窒素含量が凝固時雾囲 気圧力に関係なく，ほぼ一定の值を示したものと考えら れる.

以上のように, 減圧下における $\mathrm{Fe}-\mathrm{N}$ 系の気孔生成 現象は, 溶質量を考慮した溶鉄中における気泡の安定存 在条件（球冠気泡形成に必要な極小窒素濃度）により， 定性的に説明できることがわかつた。

\section{3 固液界面前方に㵊化される窒素量について}

前節で考察したよらに，Fe-N 系の気孔生成挙動は球 冠気泡形成条件の解析結果と定性的な一致を示したが， 実際の気孔生成はこの解析結果よりも常に低い濃度で達 成されている，このことは，気孔生成現象に対し，凝固 過程に括ける溶質 (窒素) の前面濃化現象も重要な役割 を果たしていることを示すものと考えられる.

そこで，Fig. 6 に示すような一次元平面凝固モデル を基に，前面濃化現象により固液界面前方に濃化される 窒素量と気孔生成現象の関係について考察する。なお，

Fig. 6 において，Xは凝固距難，Yは凝固の定常状態 における固液界面からの距離であり， $C_{\mathrm{sol}}(\mathrm{X})$ 拈よび $C_{1 \mathrm{iq}}(\mathrm{X}) ， C_{1 \mathrm{q} q}(\mathrm{Y})$ は，それぞれ距離 $\mathrm{X}$ あるいはYにお ける固相および液相の溶質濃度である。また， $k$ および $C_{0}$ は分配係数および初期溶質濃度である.

この一次元平面凝固モデルによれば，固相から排出さ

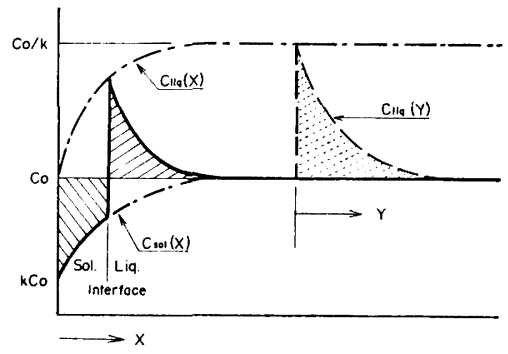

Fig. 6. Solute distribution during uniaxial solidification.

れた溶質（固液界面固相側の斜線部分）は，固液界面液 相側にピーク濃度 $C_{1 \mathrm{iq}}(\mathrm{X})$ を有する前面濃化層（固液 界面液相側の斜線部分）を形成する.この前面濃化現象 による気孔生成条件は，一般的には $C_{11 q}(\mathrm{X})$ の值が融 液中における気泡の安定存在条件である $(1)$ 式を満す濃 度を超えることによるものと考えられている。

しかしながら，前節で考察したよらに，ある体積の気 泡が形成されるためにはその気泡周囲の溶質濃度は(4) 式を満足せねばならない.したがつて，前面濃化現象に よる気孔生成条件は, 単に $C_{1 \mathrm{iq}}(\mathrm{X})$ の值によつて決ま るのではなく, 気泡形成に関与する前面濃化層内の溶質 濃度と量が（4)式を満足するか否かといらことになる.

そこで, 凝固過程において固相から排出され，前面濃 化層内に濃化された溶質量について考壳てみよう.

Fig. 6 からわかるように, 固相から排出された全溶 質量は, $C_{\mathrm{sol}}(\mathrm{X})$ あるいは $C_{11 \mathrm{q}}(\mathrm{Y})$ をおのおの距離 $\mathrm{X}$ あるいはYについて零から無限大まで積分することによ つて求めることができるが，終末トランジェント領域を 除き, 気孔生成の臨界は定常状態領域にあり, かつ考察 の対象が前面濃化層の濃度分布と関連することから, 定 常状態における固液界面液相側の溶質濃度分布を与える 次式吕をを用いて計算することとする.

$$
C_{1 \mathrm{iq}}(\mathrm{Y})=C_{0}+C_{0}[(1-k) / k] \exp \left(-V \mathrm{Y} / D_{1 \mathrm{iq}}\right)
$$

ここで，Vは凝固速度， $D_{11 \mathrm{q}}$ は液相に打ける溶質の拡散 係数である.なお，計算にあたつては，(5)式を $C_{0}$ で 除して無次元化し, 次式で示すようにYについて積分し た.

$$
\begin{aligned}
\int_{0}^{\infty}\left[C_{1 \mathrm{iq}}(\mathrm{Y}) / C_{0}-1\right] d \mathrm{Y} \\
=\int_{0}^{\infty}[(1-k) / k] \exp \left(-V \mathrm{Y} / D_{11 \mathrm{q}}\right) d \mathrm{Y}
\end{aligned}
$$

また，(6)式の計算において, 凝固速度 $V$ には本実験に おける溶鉄の凝固速度 $1 \mathrm{~cm} / \mathrm{s}$ の值を, 溶質の拡散係数 $D_{11 q}$ には溶鉄中に护ける窒素の払散係数 $\approx 10^{-4} \mathrm{~cm}^{2} / \mathrm{s}$ 


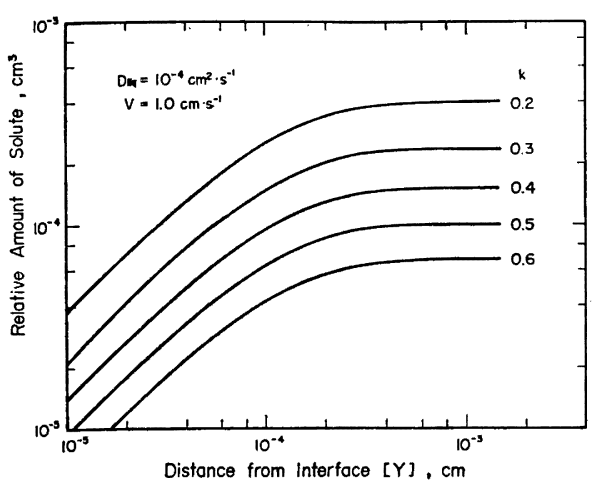

Fig. 7. Amount of solute in diffusible boundary layer plottep against distance from interface of solid-liquid for various values of distribution coefficients.

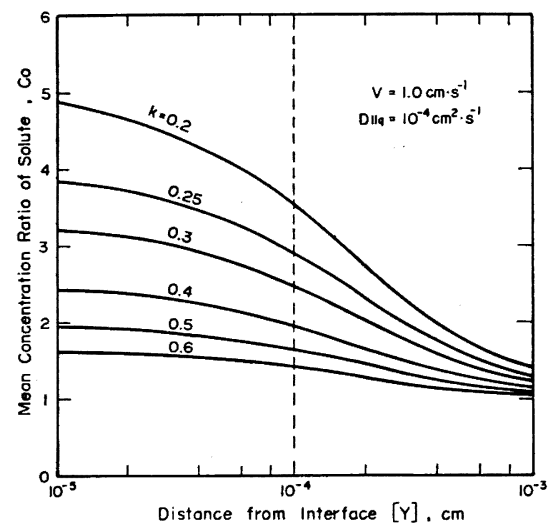

Fig. 8. Relationship between mean concentration of solute and distance from interface of solid-liquid in various distribution coefficients.

$\left(1536^{\circ} \mathbf{C}\right)^{24)}$ の值を使用し，積分には数値積分法（ガウ ス 5 点法, 積分刻み幅 $10^{-7} \mathrm{~cm}$ ) を適用した.

いくつかの分配係数の值について，(6)式を計算して 得られた溶質量を, 距離 $\mathbf{Y}$ とその距離内に存在する溶質 量との関係にまとめ，Fig. 7 に示す.なお，図中の相 対溶質量 (縦軸) は, 晶出する固相の凝固界面表面積が 単位面積である場合に，濃化される溶質量を任意の $C_{0}$ を有する融夜の体積 $\left(\mathrm{cm}^{3}\right)$ で表わしたものである.

Fig. 7 に見られるように，前面濃化層内の溶質量は， いずれの分配係数についても距離 $\mathrm{Y}$ の増加とともに指数 関数的に増大（溶質濃度は指数関数的に減少）するが, 前面濃化層の特性距離 $\left(D_{1 \mathrm{Iq}} / V=10^{-4} \mathrm{~cm}\right)$ 付近より增 加傾向は次第にゆるやかとなり，約 $6 \times 10^{-4} \mathrm{~cm}$ 付近で ほぼ一定の值（固相から排出された全溶質量に対応）と
なつているまた同図より，距離Yが極めて小さい範囲 では，その溶質濃度は十分に高いにもかかわらず，その 距離内に存在する溶質量が少ないため（たとえば， $\mathrm{Y}=$ $10^{-5} \mathrm{~cm}, k=0.3$ の場合, 溶質濃度は約 $3.1 C_{0}$, 溶質量 は固相から排出された全溶質量の約 $9 \%$ ), 気泡形成の可 能性が著しく小さいことが推定される.

Fig. 8 は, 距離 $\mathrm{Y}$ 内に存在する溶質量を, 距離 $\mathrm{Y} て ゙$ の平均濃度 $\left(C_{0}=1\right)$ として表したものである. ここで 注目されることは, 距離 $\mathrm{Y} か ゙$ 前面濃化層の特性距離（図 中破線）付近までは，平均溶質濃度の变化が比較的緩慢 な点である.これは，Fig. 7 からわかるように, 固相 から排出された溶質の大半（約 63\%）が特性距離内に 存在することによるものである. また，この特性距離で は, $C_{1 \mathrm{lq}}(\mathrm{Y})$ の值は $C_{1 \mathrm{iq}}(\mathrm{X})$ の值の $1 / e(k=0.3$ で約 $\left.1.9 C_{0}\right)$ であり, 溶質量および溶質濃度の両者とも, 前 面濃化層の特徵をよく表している領域と考えられる.

そこで，前面濃化層における気泡形成条件を，この特 性距離における平均溶質濃度と溶質量によつて代表させ 考察を進めることとする.なおこの場合, 気泡形成条件 は, 特性距離における平均溶質濃度が ( 4 ) 式を满足すれ ばよいことになる。

Fig. 8 には，いくつかの分配係数に対する計算結果 を示しているが，ここで凝固過程の分配係数として $\mathrm{Fe}$ $\mathrm{N}$ 系の平衡分配係数 $k_{0}=0.3$ の值を用いると, 特性距 離での平均溶質濃度は初期濃度の約 2.5 倍に達すること になる．したがつて，前節で考察した球冠気泡モデルの 場合, 融液の初期溶質濃度が（4)式を満足するために必 要な濃度よりも約 $2 / 5$ 程度低い濃度であつても, 固夜界 面で気泡の形成が可能となることになる。

以上のよ5に，凝固過程における前面濃化現象を考虑 すれば，初期窒素濃度が(4) 式を满足する濃度以下にお いても気泡を形成しらる 条件の存在することがわかつ た.このことはまた, 本実験で得られた気孔生成の臨界 窒素含量が，溶鉄中における球冠気泡形成条件の解析に よつて得られた気泡形成の極小窒素濃度よりも，常に低 い濃度を示した原因と考兄らる。

ところで，本実験のように溶融金属の凝固速度が比較 的速い場合，溶質の分配係数は一般に平衡値 $\left(k_{0}\right)$ をと らず，凝固速度に依存した実効值（実効分配係数 $k_{\mathrm{e}}$ ）を とり， $k_{0} \leq k_{\mathrm{e}} \leq 1$ となることが知られている. そこで， 本実験条件下に拈ける $\mathrm{Fe}-\mathrm{N}$ 系の実効分配係数の值を 推定してみよう.

Fig. 9 に, 前面濃化層の特性距離に括ける平均溶質 濃度と分配係数の関係を示す. 4.2 節で示したように, 実験的に得られた気孔生成の臨界窒素含量（約 10 Torr 


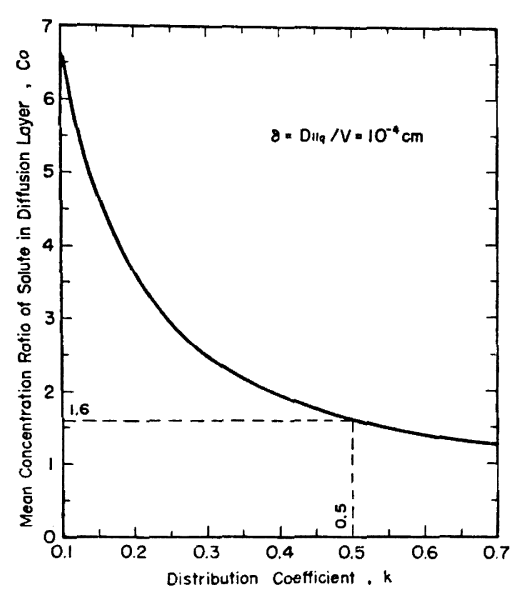

Fig. 9. Solute concentration plotted against distribution coefficient.

以上）は，球冠気泡形成に必要な極小窒素濃度の約 $5 / 8$ の値となつている、このことは, 気孔生成の臨界窒素含 量を初期窒素濃度とする溶鉄が凝固する際に，特性距離 の平均窒素濃度が初期濃度の 1.6 倍となる条件が気孔生 成の臨界条件であり，その実効分配係数を示すことにな る.

Fig. 9 には上述の関係を破線で示してあるが，これ より本実験における実効分配係数は約 0.5 と推定され る.

\section{4 気孔発生形態について}

Photo. 2 に示したように，凝固試料中には，円筒状 気孔，くさび状気孔，引忖笨状気孔拈よび球状気孔の 4 形態が観察された。このよらな気孔発生形態の差異は, 主として凝固速度と気泡成長速度の相関関係に起因する ものと考えられる25)。しかし，本実験に拈ける溶鉄の凝 固速度はいずれの試料についてもほぼ一定であることか ら，その気孔発生形態は気泡の成長速度に依存している ものと考えられる。

そこで，前面濃化層内で形成された球冠気泡の成長過 程についてみると，この気泡が成長するためには，その 気泡周囲の溶鉄窒素濃度が少なくとも気泡内圧に対応す る平衡窒素溶解量 $\left(C_{\mathrm{e}}\right)$ 以上であることが必要となる. したからて, 気泡の成長過程は, 前面濃化層の前方に存 在する溶鉄の窒素濃度（初期空素濃度 $C_{0}$ に等しい）の $C_{\mathrm{e}}$ に対する過飽和度によつて，Fig. 10 の模式図に示 すような 3 種類の成長過程を考えることができる。なお 図中， $C_{\mathrm{r}}$ は実験的に得られた気孔生成の臨界窒素含量 であり, $C_{0}=C_{\mathrm{r}}$ の場合, 前面濃化層内の平均窒素濃度 はほぼ $C_{\boldsymbol{\theta}}$ となる。 また，困中の矢印は，気泡一溶鉄間

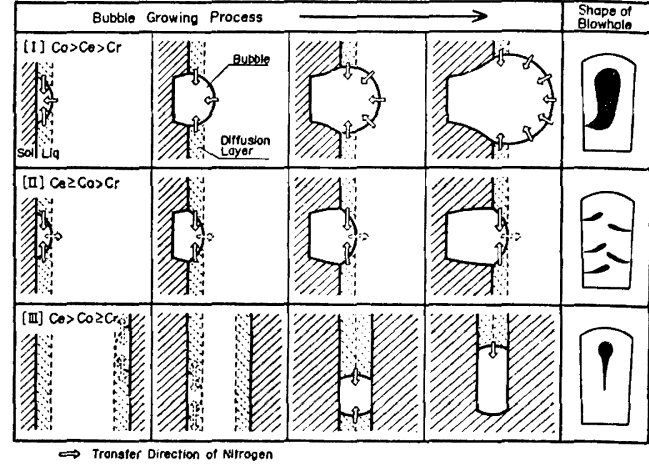

Fig. 10. Effect of initial concentration of solute for growing bubble on its shape.

( I ) fast growth, (II) intermediate growth, (III) slow growth.

に护ける窒素の移動方向を示したものである.

(i) $C_{0}>C_{\mathrm{e}}>C_{\mathrm{r}}$ (Fig. 10-[ I ]): $C_{\mathrm{e}}$ に比べて $C_{0}$ が大きいため, 気泡は凝固の極めて初期の段階で固夜界 面に形成されらることになる，また，気泡内一の窒素の 移動は，前面濃化層およびその前方の溶鉄を含めたすべ ての気液界面から生じるため, 気泡は凝固速度に依存寸 ることなく前面濃化層を超えて自由に成長できることに なる，さらに，その成長にともない，気液界面積の增大 および気泡内圧の低下がより顕著となるため，気泡の成 長速度は加速度的に增大することになる．この場合，最 終的な気孔発生形態は, 初期凝固部で発生した気孔が最 終凝固部一向かつて急激に成長する円筒状気孔となる。 のと考えられる.

(ii) $C_{\mathrm{e}} \geq C_{0}>C_{\mathrm{r}}$ (Fig. 10-[II]) : この場合も (i) と同様に, 気泡の形成は凝固の比較的初期の段階で生じ る窒素濃度にある. しかし, 溶鉄から気泡内一の窒素の 移動は前面濃化層内の気液界面を介してのみ生じるた め, 気泡は前面濃化層を超えて成長することが困難とな る（前面濃化層を超えて成長した場合，その前方の溶鉄 中への気泡から窒素が溶解することも考えられる). し たがつて, 気泡の成長速度は前面濃化層の形成速度, 換 言すれば凝固速度とほぼ等しい速度で成長することにな る. 最終的な気孔形態は, 初期凝固部で発生した気孔が 凝固組織に沿つて細長く成長したくさび状気孔となると 考えられる。

(iii) $C_{\mathrm{e}}>C_{0} \geq C_{\mathrm{r}}$ (Fig. 10-[四]）：この場合, 前面 濃化層内の堂素濃度は, 気泡を形成しらる臨界値近傍に あり， $C_{0}$ の値が $C_{\mathrm{r}}$ に近いほど定常状態領域での気泡 形成・成長の機会が減少することになる、したがつて, 定常状態領域で気泡形成が生じなかつた場合, 気泡形成 
の機会は終末トランジェント領域まで持越されることに なり，図中に示したように，最終凝固部（試料中央部） で対向する前面濃化層同志が会合するような場合に気泡 が形成され，急速に成長することになる．気孔の発生形 態は，最終凝固部で垂直に成長した引け巣状気孔となる ものと考えられる.なお，試料中央上部に観察される球 状気孔は, この引け巣状気孔の頭部のみが残留したもの であると考えられる。

前揭の Photo. 2 は, 上述の各気泡成長過程に対応す る気孔発生形態の典型的な一例を示したものであるが， その窒素分析值を基に，溶鉄の初期窒素濃度の過飽和度 を考えてみよう。なお， $C_{\theta}$ の值には，球冠気泡形成に 必要な極小空素濃度 $(4 \cdot 2$ 節) を採用することとする.

円筒状気孔（Photo. 2-a) の場合，その気孔発生点は 溶鉄表面から約 $10 \mathrm{~mm}$ の深さにある.この深さにお打 る $C_{\theta}$ の值は Fig. 5 より約 $40 \mathrm{ppmN}$ であり， $C_{0}$ の 值は試料の窒素分析值より $70 \mathrm{ppmN}$ である。したがつ て，初期窒素濃度の過飽和度 $C_{0} / C_{\theta}$ は約 1.8 となり， 初期窒素濃度は上述した（i ）の気泡成長過程に対応す る過飽和濃度にあることがわかる。

次に, くさび状気孔 (Photo. 2-b) の場合, $C_{0} / C_{\theta}$ 値 は約 $1.1\left(C_{0}=310 \mathrm{ppmN}, C_{\mathrm{e}}=280 \mathrm{ppmN}\right)$ であり，そ の初期窒素濃度は大略（ii）の気泡成長過程領域にある ことを示している.

また，引け巣状気孔拉よび球状気孔 (Photo. 2-c およ び 2-d) の場合， $C_{0} / C_{\mathrm{e}}$ 值はそれぞれ 約 $0.7\left(C_{0}=57\right.$ $\left.\mathrm{ppmN}, C_{\mathrm{e}}=82 \mathrm{ppmN}\right)$ 扎よび約 $0.8\left(C_{0}=68 \mathrm{ppmN}\right.$, $C_{\mathrm{e}}=82 \mathrm{ppmN}$ ) であり，これらの初期窒素濃度は（iii） の気泡成長過程を示す濃度領域にあることになる。

このように，本実験において観察された円筒状気孔， くさび状気孔，引け巣状気孔および球状気孔の形成機構 は, 前面濃化層内における球冠気泡形成に必要な窒素濃 度に対する初期窒素濃度の過飽和度によつて説明できる ことが明らかとなつた．またこのことは，前面濃化現象 による基本的な気孔発生形態としては, 円简状気孔， く さび状気孔および引け巣状気孔の 3 形態のみが可能であ ることを示するのである。

以上, 凝固過程における前面濃化現象を基に, 固液界 面で形成された気泡の成長過程と気孔発生形態の関係に ついて考察したが，溶鉄中での気泡生成にはこの他，溶 鉄が凝固点に椧却する間に，溶鉄中で均質あるいは不均 質核生成により気泡の形成される場合も考光られる.

この場合，溶鉄中で形成された気泡は，融液中で最む 安定な形状である球状を呈するものと考学られる（不均 質核生成の場合も，その成長により気泡径は核生成物質
より大となる)・したがつて，この球状気泡が溶鉄中で 安定に存在するためには，その気泡周囲の窒素濃度は Fig. 5 に示したよらに，凝固界面で形成される球冠気 泡に比べて極めて高い濃度を必要とすることになる.

本実験においては，溶鉄中に球状気泡を形成しらるよ らな高窒素濃度での実験例はないが，もし溶鉄にそのよ らに高い窒素濃度が与えられた場合には，凝固試料中に 微小な球状気孔を生成することも考えられる。

しかし，これまでの考察からわかるよらに， Fe-N 系 では, その凝固過程においても凝固界面で気泡の形成. 成長が生じる. しかも，球状気孔が形成されるような条 件では, その初期窒素濃度が $C_{\mathrm{e}}$ よりも著しく高い $\left(C_{0} 》\right.$ $\left.C_{\theta}\right)$ ことになり，凝固界面で形成された気泡は極めて急 速に成長し, 球状気泡の痕跡をも消隇させてしまうもの と考えられる。

また，不均質核生成により形成された気泡が，核生成 物質よりる小さい大きさを保つている場合には，溶鉄の 窒素濃度は球冠状気泡の形成条件 (Fig. 5) とほぼ同程 度の值と考えられる. しかし，このよらな大きさの気孔 が凝固試料中に存在したとしても, 気孔として確認する ことは極めて困難であると同時に，この場合にも凝固界 面で気泡の形成・成長が生じるため，その気泡の痕跡が 残留するかどうか明らかではない。

このように，前面濃化現象により凝固界面に気泡を形 成しうる系の場合, 融液の冷却過程における気泡の形成 と気孔生成の関係を実験的に確認することは困難である う。また，このような系における気孔生成の臨界溶質浱 度は, 凝固界面に打ける気泡生成条件が支配しているも

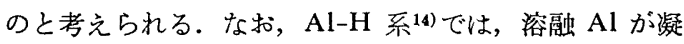
固点まで冷却する間に不均質核生成によつて形成された 気泡が凝固 $\mathrm{Al}$ 中に残留し, 微小な球状気孔を発生する ことが観察されている.

\section{5. 結}

\section{言}

$\mathrm{Fe}-\mathrm{N}$ 系を対象に，その気孔生成挙動と窒素含量なら びに凝固時雾围気仕力の関係について検討し，次の結果 を得た。

1 ) 気孔生成の臨界窒素含量は, 凝固時雾囲気圧力の 低下とともに，その圧力の $1 / 2$ 乘に比例して減少する が, 凝固時雾囲気圧力が約 10 Torr 以下では, 雾囲気 王力に関係なくほぼ一定の值（約 $40 \mathrm{ppmN}$ ) となるこ とが見出された。

2) 溶鉄中に打ける気泡の安定存在条件を, 気泡形成 に必要な窒素量の钼点から検討し, 上述の気孔生成挙動 は固液界面に拈ける球冠状気泡の形成条件之定性的に一 
致することを示した.

3 ) 前面濃化現象によつて固液界面前方に濃化される 窒素量について検討し, 上記球冠状気泡形成モデルの妥 当性を明らかにした。

4 ) これらの結果より，本実験条件下に打ける窒素の 実効分配係数を推定し， $k_{\mathrm{e}}=0.5$ の值を得た.

5 ) 凝固試料中の気孔発生形態としては, 円简状気 孔, くさび状気孔, 引け巣状気孔拉よび球状気孔の 4 形 態が観察された。

6 ) 前面濃化層内に形成された気泡の成長機構につい て検討し, 上記各気孔発生形態は前面濃化層内で球冠気 泡形成に必要な窒素濃度に対する初期窒素濃度の差異に 起因するものであることを明らかにした．

本実験に使用したレビテーション溶解反応装置の製作 飞御協力頂いた当研究所技術課の星勉技官ならびに宮代 寛技官の両氏に深甚の謝意を表します。

\section{交献}

1) 丹羽貴知藏, 下地光雄：鉄と鋼，46 (1960), p. 19

2 ) 森一美, 下田輝久, 神森章光, 出口幹郎：鉄々 鋼，59 (1973)， p. 874

3 ) 森 一美, 神森章光, 出口幹郎, 下田輝久: 鉄と 鋼, 59 (1973), p. 887

4 ) 森一美, 平岩 正, 野村宏之：鉄之鋼，61 (1975), p. 2952

5 ）野村宏之, 森一美：鉄と鋼，64（1978）, p. 1143

6) $D . A$. Hirschfeld and $F$. Weinberg: Met. Trans., 9B (1978), p. 321

7) $J$. Szekely and G. P. Martins: Trans. Met.
Soc. AIME, 245 (1969), p. 1741

8 ) $I$. $K$. Poknodnya and L. I. Demchenko: Avt. Svarka, (1977) 11, p. 8

9) D. BurNs and $J$. BeEch: Ironmaking and Steelmaking, (Quarterly), (1974), p. 239

10）加藤栄一，山中啓充，稲垣由紀雄：鉄と鋼，62 (1976), S 466

11）喜田 清：鋳物, 49(1977), p. 329

12) $U$. Bleeck, $M . G$. Frohberg, and $H$. Leygraf: Arch. Eisenhüttenw., 49 (1978), p. 167

13) 宇田雅広, 大野 悟：溶接学会誌，42 (1973), p. 225

14）宇田雅広, 大野 悟：軽金属溶接, (1973) 125, p. 215

15）宇田雅厇，大野 悟：溶接治金研究委員会資料, No. 53 (1973), WM-488-73

16）大野悟，宇田雅広：溶接冶金研究委員会資料, No. 57 (1974), WM-535-74

17）宇田雅広, 檀 武弘, 大野 悟：鉄と鋼, 62 (1976), p. 62

18）学振彆鋼19委員会：製鋼反応の推奖平衡値, (1968), p. 158 [日刊工業新聞社]

19）学振製鋼 19委員会：鉄鋼と合金元素(上), (1966) p. 593 [誠文堂新光社]

20) 文献 18), p. 2

21) L. D. Lucas: Compt. Rend., 250 (1960), p. 1850

22) B. C. Allen and W. D. Kingery: Trans. Met. Soc. AIME. 215(1969), p. 30

23) B. Chalmers: Principles of Solidification, (1964), p. 126 [John Wiley \& Sons, Inc.]

24) $H$. Bester and $K . W$. Lange: Arch. Eisenhüttenw., 43 (1972), p. 207

25) 交献 23), p. 126 